\title{
Evaluation of the Training the Trainers Programme What Did Trainers Know? - What Did They Learn?
}

Edward M. Scahill

Department of Economics, University of Scranton

\begin{abstract}
From 1995 to 2003 over 700 educators from the former Soviet Union and Central and Eastern Europe participated in a programme that trained them to provide services similar to those offered by centres for economic education affiliated with universities and colleges in the United States. This paper summarises pretest and post-test data to evaluate the educators' knowledge of fundamental microeconomics and macroeconomics. These results are compared to data for over 2,700 US college students who participated in the norming of the same test items used to evaluate the training programme.
\end{abstract}

\section{Introduction}

In 1949 the National Council on Economic Education (NCEE), then called the Joint Council on Economic Education, began building a network of state organizations (councils) and university-based centres for economic education to increase and improve the teaching of economics at the pre-college level in the United States. The primary means the NCEE network uses to accomplish its mission is teacher training. The rationale for training current and future teachers to teach economics, rather than attempt to teach students directly, is twofold. First, the initial monetary and human cost of providing instruction to teachers is much less than the cost of providing instruction to students directly. Second, each trained teacher has the potential to affect thousands of students over time (the 'multiplier principle'). 
The economic and political reforms that began in the former Soviet Union and Central and Eastern Europe in the late 1980s provided an opportunity for the NCEE to apply proven training methods to an entirely new group of educators, many of whom had little familiarly with the operation of a market economy. From 1995 to 2003 the NCEE, through its Cooperative Education Exchange Program (CEEP), sponsored a series of programmes for educators from the former Soviet Union and Central and Eastern Europe. The educators were given instruction in economic theory and the operation of a market economy, and how to teach economics through the use of various classroom activities. A special programme - Training the Trainers - was offered during this period to over 700 educators. Training the Trainers prepared individuals to provide services similar to those offered by centres for economic education affiliated with universities and colleges in the United States.

The primary argument for the multiplier principle - it enables councils and centres to make efficient use of scarce monetary and human resources - is even stronger in nations with low levels of per capita income and few private and public sources of funding for education. The role of the trainers (this term will refer to those who received instruction, rather than those who served as instructors, during the Training programmes) is critical to the development of economic literacy in nations experiencing a transition from a command system to a form of market economy.

The length and content of each Training programme was similar in all years: four one-week sessions (six days of instruction per session, approximately seven hours per day). Topics for the four sessions were fundamental concepts, microeconomics, macroeconomics and international economics. In any year either two or three Training programmes were conducted. Instruction was in English with lectures translated into Russian. Participants were given the option of completing testing and evaluation materials in either Russian or English. The only exceptions to this were two programmes conducted in 1996-97 and 1997-98 for trainers from Ukraine. For these programmes lectures, testing and evaluation materials were translated into the trainers' native language.

\section{Previous research on the impact of teacher training on student learning}

An implication of the multiplier principle is that training teachers to learn and teach economics will be an effective means of educating students. A number of studies have provided empirical support for the effectiveness of the multiplier principle. Walstad and Soper (1988) found a statistically significant relationship between the number of college credit courses teachers take and their students' pretest and posttest performance on the Test of Economic Literacy (TEL), a standardised test used 
primarily with high school students, after accounting for the stock of student knowledge prior to the courses during which tests were taken. Watts and Bosshardt (1990) examined the impact high school economics teachers' personal characteristics had on the effectiveness of their teaching. They found that student gains in post-test scores, again using the TEL, were highest among students whose teachers had the most training in economics. Lynch (1990) found that measured gains (pretest to post-test, using the TEL) in student understanding were related to the number of economics courses taken by their instructors. Lynch also found that '...the only situation when students, as a group, will have a statistically significant gain in learning is when they are taking an economics course from a well-trained instructor... students learn more when their teachers have more training...' (p. 295).

Walstad and Rebeck (2001) examined the level of understanding of economics, measured by performance on a 23-item version of the TEL, by students from four transitional nations (Lithuania, Poland, the Ukraine and Kyrgyzstan). The students were divided into two groups: those taught by participants in an NCEE-sponsored programme held in 1996 or 1997 (the experimental group) and students taught by teachers who did not participate in one of these programmes (the control group). Pretest results showed that students from the experimental and control groups were similar in their knowledge of economics; the performance of the experimental group on the post-test was greater than that of the control group. Despite concerns about the conditions surrounding the student tests (e.g. experimental group teachers may have had greater motivation and enthusiasm for their subject than the control group teachers) the authors found that the level of teacher understanding of economics had a positive impact on student understanding in the experimental group.

\section{Research focus}

The research results presented in this paper address two fundamental questions.

\section{What did the trainers know?}

This question is addressed by examining the trainers' performance on pretest measures of knowledge of fundamental microeconomic and macroeconomic concepts. ${ }^{1}$ Other pretest (and post-test) data were obtained, including measures of trainers' attitudes towards economic issues, their views of important elements of market economies and their teaching styles and methods. This paper is concerned only with measures of economic knowledge because of the important role trainers assume in promoting economic education in their home countries. A key determinant of the success of these efforts is the recruitment of competent centre 
directors and related personnel; this is no less true in Europe and Asia than it is in the United States. Therefore, it is important to ascertain the trainers' level of economic understanding prior to their participation in Training programmes.

There were 746 participants in the Training programmes from 23 different countries. ${ }^{2}$ The programmes began just a few years after the beginning of dramatic changes in these nations' political, economic and educational institutions, the consequences of which would have profound effects for decades to come. Among the reforms begun in many of these countries is a change in the economics curricula of colleges and universities. In describing the reforms in undergraduate economics initiated in Russia, Kovzik and Watts (2002) describe new economics standards established at Moscow State University 3 and the impact they have had on the selection of textbooks, faculty training and course offerings. Many of these initiatives have been adopted by other universities in the former Soviet Union. Ultimately, students from these universities will receive instruction in mainstream western economics similar to that offered by universities in the United States and western Europe. But the transition will take years, if not decades, to complete. Kovzik and Watts commented on the difficulty of making fundamental changes in the economics curriculum in Russia.

'... the people teaching the courses in the new curriculum were, for the most part,... the same people who taught economics courses in the old curriculum... Using instructors with little or no formal training in western economics, and indeed who were trained in very different and often conflicting approaches may be, as Brue and MacPhee noted, "like assigning a creationist to teach evolution" (1995: 189)... using translations of US or western textbooks... solves some problems, but creates others in terms of relevance of examples used in books and discussions of institutions... [and] there is considerable bureaucratic and individual faculty opposition to wholesale and uncritical adoption of western economics... there is more support for market reforms among younger segments of the population in eastern Europe and the [former Soviet Union] than there is among older groups (Kovzik and Watts, 2002: 38).'

It is difficult to assess the effect these developments had on the trainers' pretest knowledge of economics. Some trainers may have been recent products of their education systems and were relatively well-versed in mainstream economic theory. However, some trainers attended undergraduate and graduate institutions prior to the reforms. In addition to differences in economic literacy among the trainers' in any one year, differences in understanding across years in which the Training programmes were held were also expected. One may alternatively assume: 
- the most eager and capable trainers will have been first to volunteer for Training opportunities so that mean pretest scores will be higher in earlier years than later years, or

- those trained in later years had more exposure to market-oriented economics programmes as curriculum changes in their own countries became broader and more developed. If true, the mean pretest scores of trainers (ceteris paribus) from the later years would be greater than scores of trainers from earlier years.

\section{What did the trainers learn?}

The second questioned is addressed by analyzing the trainers' post-test microeconomics and macroeconomics test scores. The post-test results provide evidence of the trainers' ability to learn economics as well as the programme instructors' ability to communicate with audiences from widely different cultural and educational environments. Although improvement in programme instruction over time was expected due to learning by doing, there were wide differences among the trainers' backgrounds, motivation to learn, language skills, etc. It may be that trainers from some nations were more enthusiastic about the Training programmes and had more positive attitudes towards their nations' adoption of market principles than trainers from other nations. But it is not clear that a relatively large number of highly motivated trainers should be expected in either the early or later years of the programme.

\section{Test instruments}

The test items used to assess trainers were taken from the third edition of the Test of Understanding in College Economics or TUCE (Saunders, 1991). Of the 33 items included in the microeconomics TUCE, 17 were used on all of the pretests and posttests administered to participants in the Training programmes from 1996 to $2003 .{ }^{4}$ Of the 33 items included in the macroeconomics test, 18 were administered to participants in each of the Training programmes. Since the TUCE items are the product of careful assessment and selection by a committee of economists and economic educators, and have published norms, they are well suited for research purposes. Test scores from the TUCE norming samples provide a basis for comparing the trainers' test scores. ${ }^{5}$

Table 1 classifies the test items by their content categories. TUCE items used to test the trainers cover five of the six categories used to classify the complete TUCE. A sixth content category, international economics, was not represented in the trainers' tests. Table 1 also classifies test items by three cognitive categories. These categories are based on Bloom's taxonomy of educational objectives. (Saunders, 1991:3). ${ }^{6}$ 
Table 1 Classification of item numbers by TUCE content categories

\begin{tabular}{|c|c|c|c|c|c|}
\hline & & \multicolumn{4}{|c|}{ Cognitive categories } \\
\hline & & $\begin{array}{l}\text { Recognition } \\
\quad \text { and } \\
\text { understanding }\end{array}$ & $\begin{array}{l}\text { Explicit } \\
\text { application }\end{array}$ & $\begin{array}{l}\text { Implicit } \\
\text { application }\end{array}$ & $\begin{array}{l}\text { No. of } \\
\text { items }\end{array}$ \\
\hline \multicolumn{6}{|c|}{ Macroeconomics } \\
\hline A & $\begin{array}{l}\text { Measuring aggregate economic } \\
\text { performance }\end{array}$ & 1 & 2 & 12 & 3 \\
\hline B & $\begin{array}{l}\text { Aggregate supply, productive } \\
\text { capacity and economic growth }\end{array}$ & 7 & 3 & - & 2 \\
\hline C & $\begin{array}{l}\text { Income and expenditure } \\
\text { approach to aggregate demand } \\
\text { and fiscal policy }\end{array}$ & 8,21 & 9 & 25 & 4 \\
\hline D & $\begin{array}{l}\text { Monetary approach to aggregate } \\
\text { demand and monetary policy }\end{array}$ & 11,26 & 14 & - & 3 \\
\hline $\mathrm{E}$ & Policy combinations & - & 13 & $\begin{array}{l}15,23 \\
24,28,29\end{array}$ & 6 \\
\hline & Total number of items & 6 & 5 & 7 & 18 \\
\hline \multicolumn{6}{|c|}{ Microeconomics } \\
\hline & The basic economic problem & 1 & 5 & 24 & 3 \\
\hline B & Markets and the price mechanism & 21 & 9,15 & 29 & 4 \\
\hline C & $\begin{array}{l}\text { Costs, revenue, profit maximisation } \\
\text { and market structure }\end{array}$ & 4,28 & 23 & 3 & 4 \\
\hline D & $\begin{array}{l}\text { Market failures, externalities, } \\
\text { government intervention and } \\
\text { regulation }\end{array}$ & 10,25 & - & - & 2 \\
\hline \multirow{2}{*}{ E } & $\begin{array}{l}\text { Income distribution and } \\
\text { government redistribution }\end{array}$ & 12 & 16,26 & 13 & 4 \\
\hline & Total number of items & 7 & 6 & 4 & 17 \\
\hline
\end{tabular}

Source:Test of Understanding in College Economics (3rd edn.) (1991), Phillip Saunders, Joint Council on Economic Education, 11-12. 


\section{Descriptive statistics}

A total of 15 Training programmes were conducted from 1996 to 2003. Seven were designated 'English/Russian Language' in which instruction was given in English and translated into Russian. Trainers were given the option of completing tests and evaluation materials written in either Russian or English. Another six programmes were 'Russian Language' in which instruction was given in English and translated into Russian; test and evaluation materials were translated into Russian. Two programmes were conducted exclusively for Ukrainian trainers with instruction given in English and translated into Ukrainian. Tests and evaluation instruments were translated into Ukrainian for these groups.

Two different organisations (Educational Development Center from 1995 to 2001 and Macro International Inc from 2001 to 2003) served as programme evaluators. As a result, the content and wording of evaluation materials were not the same for all of the Training programmes. Descriptive statistics and test data are incomplete or unavailable for some programmes. Table 2 summarises selected trainer characteristics. Relatively few trainers ( 35 or $4.6 \%$ of those who began the Training programmes ${ }^{7}$ ) had received doctoral degrees while a much larger number (285 or 37.7\%) earned master's degrees. ${ }^{8}$ Perhaps the most notable observation from Table 2 is the large percentage (70.5) of female participants. One possible explanation is that the CEEP chose as its target audience individuals whose primary responsibility was teacher training. Many of these are secondary teachers or employees of nongovernmental organisations that train teachers. These teaching and training positions are often filled by women.

The large number of trainers from the Ukraine and Russia suggests that some test results may differ from others for reasons unrelated to the trainers' knowledge of economics. Since evaluation materials were translated from English into Russia or Ukrainian in all of the sessions, natives of these two countries may have understood test items better and were able to respond faster than participants from other countries.

\section{Pretest and Post-test results}

Tables 3 and 4 compare the mean pretest and post-test scores from a norming sample of 2,726 students from US colleges and universities (Saunders, 1991:18, 20) with the mean scores from each of the Training sessions. Raw scores (the mean number of correct responses) as well as their equivalent percentage scores are listed. It is difficult to subjectively evaluate the trainers' scores; for example, only three pretest microeconomic mean scores and five pretest macroeconomic mean scores exceed $50 \%$. One should have higher expectations for future directors of centres for 
Table 2 Training the Trainers: selected descriptive characteristics

\begin{tabular}{|c|c|c|c|c|c|c|}
\hline & \multicolumn{2}{|l|}{ Gender } & \multicolumn{2}{|c|}{ Home country } & \multicolumn{2}{|c|}{ Highest Degree } \\
\hline & Male & Female & Ukraine & Russia & Doctorate & Master's \\
\hline \multicolumn{7}{|l|}{ 2002-03 } \\
\hline Russian ( $n=51$ ) & 18 & 31 & 0 & 30 & 2 & 13 \\
\hline English/Russian ( $\mathrm{n}=55$ ) & 14 & 41 & 22 & 0 & 5 & 21 \\
\hline \multicolumn{7}{|l|}{ 2001-02 } \\
\hline Russian ( $n=52)$ & 12 & 40 & 11 & 13 & 3 & 17 \\
\hline English/Russian $(n=49)$ & 12 & 37 & 16 & 9 & 5 & 16 \\
\hline \multicolumn{7}{|l|}{$2000-01$} \\
\hline English/Russian $(n=51)$ & 35 & 12 & 10 & 10 & 7 & 11 \\
\hline \multicolumn{7}{|l|}{ 1999-00 } \\
\hline English/Russian $(n=46)$ & 8 & 36 & 18 & 14 & 2 & 19 \\
\hline Russian $(n=50)$ & 13 & 37 & 0 & 8 & 1 & 15 \\
\hline \multicolumn{7}{|l|}{$1998-99$} \\
\hline English/Russian $(n=59)$ & 9 & 49 & 0 & 17 & - & - \\
\hline Russian $(n=55)$ & 10 & 45 & 0 & 13 & 0 & 23 \\
\hline \multicolumn{7}{|l|}{ 1997-98 } \\
\hline English/Russian $(n=51)$ & 9 & 42 & 0 & 7 & 4 & 32 \\
\hline Ukrainian $(n=50)$ & 18 & 32 & 50 & 0 & 0 & 36 \\
\hline Russian ( $\mathrm{n}=51)$ & 13 & 38 & 0 & 38 & 0 & 12 \\
\hline \multicolumn{7}{|l|}{ 1996-97 } \\
\hline English/Russian $(n=44)$ & 13 & 31 & 1 & 8 & 3 & 27 \\
\hline Ukrainian $(n=44)$ & 17 & 27 & 44 & 0 & 3 & 33 \\
\hline Russian ( $n=47)$ & 19 & 28 & 2 & 35 & 0 & 10 \\
\hline \multicolumn{7}{|l|}{ 1996-2003 } \\
\hline Total $(n=755)$ & 220 & 526 & 174 & 202 & 35 & 285 \\
\hline
\end{tabular}

economic education than for college students. On the other hand, it is unrealistic to expect trainers to have the same level of understanding as centre directors from the United States as most of the latter have Ph.D. training and years of college-level teaching experience. Given the long dominance of Marxist ideology and only recent exposure to mainstream economics in the trainers' home countries more modest expectations seem appropriate. The TUCE norming sample means may best be seen as minimum standards trainers should be expected to exceed. By this, admittedly modest, standard the trainers' scores can be viewed more favourably. 
For each Training session the mean scores exceed the corresponding mean scores from the TUCE norming sample; in fact, the trainers' pretest macroeconomics mean score exceed the TUCE norm mean score (5.5) by no less than 2.4 points (Russian language session in 1998-99) and as much as 5.9 points (English/Russian language session in 1998-99).

Table 3 Microeconomics pretest and post-test mean scores and TUCE norms

\begin{tabular}{|c|c|c|c|c|c|c|}
\hline $\begin{array}{l}\text { TUCE } \\
\text { Norms }(n=2,726)\end{array}$ & $\begin{array}{l}\text { Pretest } \\
\text { mean (p) } \\
5.7(33.2)\end{array}$ & & & $\begin{array}{c}\text { Post-test } \\
\text { mean (p) } \\
8.5(50.1)\end{array}$ & & \\
\hline Trainers' scores & & S.D. & $\begin{array}{l}\text { Cronbach's } \\
\text { alpha }\end{array}$ & & S.D. & $\begin{array}{l}\text { Cronbach's } \\
\text { alpha }\end{array}$ \\
\hline \multicolumn{7}{|l|}{ 2002-03 } \\
\hline Russian ( $n=51)$ & $7.8(45.9)$ & 7.8 & & $12.2(71.8)$ & 2.7 & \\
\hline English/Russian ( $n=55)$ & $6.2(36.5)$ & 3.3 & \} .718 & $7.8(45.9)$ & 3.5 & \} .779 \\
\hline \multicolumn{7}{|l|}{ 2001-02 } \\
\hline Russian ( $n=52)$ & $7.0(41.2)$ & 2.8 & & $11.6(68.2)$ & 3.1 & \\
\hline English/Russian ( $n=49)$ & $6.5(38.2)$ & 3.7 & \} .681 & $9.7(57.1)$ & 3.8 & \} .765 \\
\hline \multicolumn{7}{|l|}{ 2000-01 } \\
\hline English/Russian $(n=48)$ & $6.7(39.4)$ & 3.3 & .668 & $10.2(60.0)$ & 4.0 & .809 \\
\hline \multicolumn{7}{|l|}{$1999-00$} \\
\hline English/Russian $(n=46)$ & $7.2(42.4)$ & 3.1 & .691 & $10.0(58.8)$ & 3.9 & .802 \\
\hline Russian $(\mathrm{n}=50)$ & $6.7(39.4)$ & 2.9 & .601 & $9.1(54.1)$ & 3.3 & .698 \\
\hline \multicolumn{7}{|l|}{ 1998-99 } \\
\hline English/Russian $(n=59)$ & $7.5(44.7)$ & 3.0 & .626 & $11.0(64.7)$ & 3.8 & .799 \\
\hline Russian $(n=55)$ & $7.6(44.7)$ & 3.1 & .670 & $9.8(57.6)$ & 3.3 & .716 \\
\hline \multicolumn{7}{|l|}{$1997-98$} \\
\hline English/Russian $(n=51)$ & $7.9(46.5)$ & 3.4 & .753 & $10.2(60.0)$ & 3.2 & .709 \\
\hline Ukrainian $(n=48)$ & $7.5(44.1)$ & 3.4 & .718 & $9.9(58.2)$ & 3.0 & .650 \\
\hline Russian ( $n=51)$ & $7.3(42.9)$ & 3.1 & .653 & $9.9(58.2)$ & 3.6 & .771 \\
\hline \multicolumn{7}{|l|}{$1996-97$} \\
\hline English/Russian ( $n=42)$ & $9.4(55.3)$ & 3.9 & .813 & $13.2(77.6)$ & 3.5 & .817 \\
\hline Ukrainian $(n=42)$ & $8.7(51.2)$ & 2.9 & .608 & $10.3(60.6)$ & 2.8 & .579 \\
\hline Russian $(n=46)$ & $10.2(60.0)$ & 3.3 & .711 & $13.2(77.6)$ & 1.7 & .170 \\
\hline
\end{tabular}

Note: $(p)$ refers to the mean score as a percentage of the total number of test items. 
In all but one instance (English/Russian language 2002-03) the trainers' post-test microeconomics mean scores exceed the TUCE norm mean score. For two programmes (English/Russian language and Russian language, both in 1996-97) the post-test microeconomics mean score is 13.2 (77.6\%), 4.7 points higher than the TUCE mean.

Table 4 Macroeconomics and post-test mean scores and TUCE norms

\begin{tabular}{|c|c|c|c|c|c|c|}
\hline $\begin{array}{l}\text { TUCE } \\
\text { Norms }(n=2,724)\end{array}$ & $\begin{array}{l}\text { Pretest } \\
\text { mean (p) } \\
5.5(30.7)\end{array}$ & & & $\begin{array}{l}\text { Post-test } \\
\text { mean (p) } \\
8.9(49.2)\end{array}$ & & \\
\hline Trainers' scores & & S.D. & $\begin{array}{l}\text { Cronbach's } \\
\text { alpha }\end{array}$ & & S.D. & $\begin{array}{l}\text { Cronbach's } \\
\text { alpha }\end{array}$ \\
\hline \multicolumn{7}{|l|}{ 2002-03 } \\
\hline Russian ( $n=51)$ & $8.8(48.9)$ & 3.9 & \multirow[b]{2}{*}{\} .723} & $14.1(78.3)$ & 2.4 & \multirow[b]{2}{*}{\} .713} \\
\hline English/Russian $(\mathrm{n}=55)$ & $8.2(45.6)$ & 3.8 & & $11.2(62.2)$ & 3.3 & \\
\hline \multicolumn{7}{|l|}{ 2001-02 } \\
\hline Russian ( $\mathrm{n}=52$ ) & $8.8(48.9)$ & 3.2 & \multirow[b]{2}{*}{\} .680} & $14.4(80.0)$ & 2.5 & \multirow[b]{2}{*}{\} .717} \\
\hline English/Russian $(n=49)$ & $8.6(47.8)$ & 3.5 & & $11.6(64.4)$ & 3.2 & \\
\hline \multicolumn{7}{|l|}{ 2000-01 } \\
\hline English/Russian $(n=46)$ & $8.1(45.0)$ & 3.0 & .600 & $12.4(68.9)$ & 3.5 & .766 \\
\hline \multicolumn{7}{|l|}{ 1999-00 } \\
\hline English/Russian $(n=46)$ & $8.9(49.4)$ & 3.5 & .709 & - & - & - \\
\hline Russian $(\mathrm{n}=50)$ & $8.1(45.0)$ & 3.5 & .700 & - & - & - \\
\hline \multicolumn{7}{|l|}{ 1998-99 } \\
\hline English/Russian $(n=59)$ & $11.4(63.3)$ & 3.0 & .686 & $12.5(69.4)$ & 3.5 & .751 \\
\hline Russian ( $\mathrm{n}=55)$ & $7.9(43.9)$ & 3.3 & .677 & $11.3(62.8)$ & 3.2 & .690 \\
\hline \multicolumn{7}{|l|}{ 1997-98 } \\
\hline English/Russian $(n=50)$ & $9.2(51.1)$ & 3.6 & .744 & $15.0(83.3)$ & 2.8 & .736 \\
\hline Ukrainian $(n=50)$ & - & - & & - & - & \\
\hline Russian $(n=51)$ & $9.0(50.0)$ & 3.2 & .648 & $11.9(66.1)$ & 3.8 & .770 \\
\hline \multicolumn{7}{|l|}{$1996-97$} \\
\hline English/Russian $(\mathrm{n}=42)$ & $11.2(62.2)$ & 3.4 & .735 & $14.8(82.2)$ & 3.2 & .796 \\
\hline Ukrainian $(\mathrm{n}=39)$ & $9.3(51.7)$ & 2.9 & .611 & $13.4(74.4)$ & 3.1 & .724 \\
\hline Russian $(n=43)$ & $11.1(61.7)$ & 2.7 & .528 & $15.4(85.6)$ & 2.0 & .550 \\
\hline
\end{tabular}

Note: $(p)$ refers to the mean score as a percentage of the total number of test items. 
Table 5 Difference in microeconomics post-test and pretest mean scores

\begin{tabular}{|c|c|c|c|c|c|c|}
\hline & $\begin{array}{l}\text { Pretest } \\
\text { mean }\end{array}$ & S.D. & $\begin{array}{l}\text { Post-test } \\
\text { mean }\end{array}$ & S.D. & $\begin{array}{l}\text { Post-pre } \\
\text { mean }\end{array}$ & $\begin{array}{l}\text { Paired } \\
\text { sample } \\
t \text {-test } \\
\text { significance } \\
\text { level }\end{array}$ \\
\hline \multicolumn{7}{|l|}{ 2002-03 } \\
\hline Russian ( $\mathrm{n}=51)$ & 7.8 & 7.8 & 12.2 & 2.7 & 4.5 & .004 \\
\hline English/Russian $(\mathrm{n}=55)$ & 6.2 & 3.3 & 7.8 & 3.5 & 1.6 & .000 \\
\hline \multicolumn{7}{|l|}{ 2001-02 } \\
\hline Russian ( $\mathrm{n}=52$ ) & 7.0 & 2.8 & 11.6 & 3.1 & 4.6 & .002 \\
\hline English/Russian ( $n=49)$ & 6.5 & 3.7 & 9.7 & 3.8 & 3.1 & .000 \\
\hline \multicolumn{7}{|l|}{ 2000-01 } \\
\hline English/Russian ( $\mathrm{n}=48$ ) & 6.7 & 3.3 & 10.2 & 4.0 & 3.6 & .000 \\
\hline \multicolumn{7}{|l|}{$1999-00$} \\
\hline English/Russian $(n=46)$ & 7.2 & 3.1 & 10.0 & 3.9 & 2.8 & .000 \\
\hline Russian $(n=50)$ & 6.7 & 2.9 & 9.1 & 3.3 & 2.4 & .000 \\
\hline \multicolumn{7}{|l|}{ 1998-99 } \\
\hline English/Russian $(n=59)$ & 7.5 & 3.0 & 11.0 & 3.8 & 3.4 & .000 \\
\hline Russian ( $\mathrm{n}=55)$ & 7.6 & 3.1 & 9.8 & 3.3 & 2.6 & .000 \\
\hline \multicolumn{7}{|l|}{ 1997-98 } \\
\hline English/Russian $(\mathrm{n}=51)$ & 7.9 & 3.4 & 10.2 & 3.2 & 2.3 & .000 \\
\hline Ukrainian $(n=48)$ & 7.5 & 3.4 & 9.9 & 3.0 & 2.4 & .000 \\
\hline Russian ( $\mathrm{n}=51)$ & 7.3 & 3.1 & 9.9 & 3.6 & 2.7 & .000 \\
\hline \multicolumn{7}{|l|}{ 1996-97 } \\
\hline English/Russian $(n=42)$ & 9.4 & 3.9 & 13.2 & 3.5 & 3.8 & .000 \\
\hline Ukrainian $(n=42)$ & 8.7 & 2.9 & 10.3 & 2.8 & 1.6 & .000 \\
\hline Russian $(n=46)$ & 10.2 & 3.3 & 13.2 & 1.7 & 3.0 & .000 \\
\hline
\end{tabular}

For each Training session post-test macroeconomics mean scores exceed the posttest TUCE norm by amounts ranging from 2.3 points (English/Russian language in 2002-03) to 6.5 points (Russian language session in 1996-97). Measures of the internal consistency of the pretests and post-tests (Chronbach's alpha9) are reported in Tables 3 and 4 . In most cases the alpha values exceed 0.70, a reasonable minimum standard for basic research. (Cronbach and Meehl, 1955). ${ }^{10}$ 
Table 6 Difference in macroeconomics post-test and pretest mean scores

\begin{tabular}{|c|c|c|c|c|c|c|}
\hline & $\begin{array}{l}\text { Pretest } \\
\text { mean }\end{array}$ & S.D. & $\begin{array}{l}\text { Post-test } \\
\text { mean }\end{array}$ & S.D. & $\begin{array}{l}\text { Post-pre } \\
\text { mean }\end{array}$ & $\begin{array}{l}\text { Paired } \\
\text { sample } \\
\text { t-test } \\
\text { significance } \\
\text { level }\end{array}$ \\
\hline \multicolumn{7}{|l|}{ 2002-03 } \\
\hline Russian ( $\mathrm{n}=51)$ & 8.8 & 3.9 & 14.1 & 2.4 & 5.3 & .005 \\
\hline English/Russian ( $n=55)$ & 8.2 & 3.8 & 11.2 & 3.3 & 3.0 & .000 \\
\hline \multicolumn{7}{|l|}{ 2001-02 } \\
\hline Russian ( $\mathrm{n}=52$ ) & 8.8 & 3.2 & 14.4 & 2.5 & 5.6 & .002 \\
\hline English/Russian ( $n=49$ ) & 8.6 & 3.5 & 11.6 & 3.2 & 3.1 & .000 \\
\hline \multicolumn{7}{|l|}{ 2000-01 } \\
\hline English/Russian $(n=46)$ & 8.1 & 3.0 & 12.4 & 3.5 & 4.3 & .009 \\
\hline \multicolumn{7}{|l|}{ 1998-99 } \\
\hline English/Russian ( $n=59$ ) & 11.4 & 3.0 & 12.5 & 3.5 & 1.1 & .000 \\
\hline Russian ( $\mathrm{n}=55$ ) & 7.9 & 3.3 & 11.3 & 3.2 & 3.5 & .000 \\
\hline \multicolumn{7}{|l|}{ 1997-98 } \\
\hline English/Russian $(n=50)$ & 9.2 & 3.6 & 15.0 & 2.8 & 5.8 & .000 \\
\hline Russian $(\mathrm{n}=51)$ & 9.0 & 3.2 & 11.9 & 3.8 & 2.9 & .000 \\
\hline \multicolumn{7}{|l|}{ 1996-97 } \\
\hline English/Russian ( $n=42)$ & 11.2 & 3.4 & 14.8 & 3.2 & 3.6 & .000 \\
\hline Ukrainian $(\mathrm{n}=39)$ & 9.3 & 2.9 & 13.4 & 3.1 & 4.1 & .000 \\
\hline Russian $(n=43)$ & 11.1 & 2.7 & 15.4 & 2.0 & 4.3 & .000 \\
\hline
\end{tabular}

Paired sample $t$-tests were conducted for the differences between each of the trainers' mean post-test and pretest scores. Tables 5 and 6 list the results. For each Training session post-test scores show statistically significant increases from pretest scores. The data suggest that the three groups trained in the 1996-97 programmes were especially capable as they earned the highest pretest microeconomics mean scores and three of the four highest pretest macroeconomic mean scores. However, there is little difference in the pretest microeconomics scores of any of the other groups. Pretest macroeconomics mean scores are higher for the earlier years (1996-97 to 1998-99) than for the later years (2000-2003). Overall, the mean scores indicate the Training programmes were successful in improving the trainers' level of economic understanding. 
The pretest and post-test scores were affected by many factors. To evaluate the separate influence of some of these factors regression analysis was used with test scores as dependent variables and individual and group characteristics as regressors for 2001-03. This period was chosen because the data collected by Macro International Inc. during this period were recorded in a consistent manner.

\section{Model}

The trainers differed with respect to gender, age, years of teaching experience, nation of origin, etc. To estimate the influence of these variables on pretest and post-test scores the following model - a simple regression model of a learning production function (Becker and Walstad, 1987) - was estimated. The level of economic knowledge, as measured by pretest scores earned by the trainers at the beginning of their workshops, is assumed to be a function of human capital and other inputs.

(1) $\quad \operatorname{Pre}_{\mathrm{i}}=\beta_{0}+\beta_{1} X_{1 \mathrm{i}}+\ldots \ldots+\beta_{\mathrm{k}} X_{\mathrm{ki}}$

Pre $_{\mathrm{i}}$ The pretest score in microeconomics or macroeconomics.

$X_{\mathrm{ki}} \quad$ Refers to the kth explanatory variable for the ith trainer.

The following are all dichotomous explanatory variables:

Emajor

$=1$ for trainers who majored in economics at the level of their highest degree

$=0$ for non-economics majors

It was expected that those whose major field of study at either the undergraduate or graduate level would achieve higher pretest scores than those who did not major in economics.

Doc

$=1$ for trainers whose highest earned degree was a doctoral degree

$=0$ for other trainers

Master

$=1$ for trainers whose highest earned degree was a master's or candidate

$=0$ for other trainers

Earning an advanced degree does not imply a trainer is more likely to have greater knowledge of economics or is better able to learn economics in a classroom setting. ${ }^{11}$ But it is possible that those with advanced degrees have greater analytical or technical skills than those who do not. Given this uncertainly, there was no a priori 
expectation regarding the qualitative relationship between pretest or post-test scores and these two variables. Two interaction variables were added to test whether receiving an advanced degree in economics was associated with higher test scores:

DEmajor

$=$ Emajor $\times$ Doc

MEmajor

$=$ Emajor $\mathrm{x}$ Master

Russhome

$=1$ for trainers whose home country was Russia

$=0$ for other trainers

Ukhome

$=1$ trainers whose home country was Ukraine

$=0$ for other trainers

Russia and Ukraine contributed more trainers than any other countries and there is evidence that Russia and Ukraine have been particularly aggressive in promoting economic education. 12 The expected sign for both of these variables was positive.

\section{Russlang \\ $=1$ for Russian language sessions \\ $=0$ for other sessions}

Trainers had the option of participating in Russian language sessions or English/Russian sessions. Those fluent in Russian should perform equally well in either session but those whose facility with English was greater than their Russian language skills would likely choose to participate in an English/Russian session. The expected sign for this variable is positive.

Sex

$=1$ for males

$=0$ for females

Some studies have shown that males perform better than females, ceteris paribus, on multiple choice economics exams (Lumsden and Scott, 1987; Walstad and Robson, 1997). Therefore, the expected sign for this variable was positive.

There is one continuous explanatory variable: 
YrsTeach

This measures the number of years trainers taught economics prior to the beginning of their Training sessions. The expected sign of this variable would certainly be positive for instructors from nations with a history of instruction in mainstream economics but it is not clear that this qualitative relationship should be expected for those teachers from the former Soviet Union and central and eastern Europe. One could argue that those with the most experience teaching economics courses also have the most experience teaching Marxist-style economics.

Accepting there is substance to the adage that it is difficult to 'teach old dogs new tricks' there was no expectation that this variable would be either positive or negative.

(2) $\quad P s t_{\mathrm{i}}=\beta_{0}+\beta_{1} X_{1 \mathrm{i}}+\ldots . .+\beta_{\mathrm{k}} X_{\mathrm{ki}}$

Pst: the post-test score in either microeconomics or macroeconomics.

The explanatory variables for the post-test regressions include all of the variables used for the pretest regression plus the corresponding pretest variable (pre). The pretest scores are assumed to be positively related to the post-test scores. The expected signs for the explanatory variables are the same as those specified for the pretest regression.

\section{Regression results: $2001-03$}

Table 7 lists results from regressions using data from the four Training sessions held in 2001-03. The adjusted $R^{2}$ values show that: (a) the first equation accounted for $14.4 \%$ of the variance in pretest micro scores (b) the second equation accounted for $42.3 \%$ of the variance in the post-test micro scores (c) the third equation explained $16.9 \%$ of the variance in pretest macro scores and $(d)$ the fourth equation explained $42.4 \%$ of the post-test macro scores. The inclusion of the pretest variables is responsible for the higher adjusted $R^{2}$ values in the second and fourth equations.

In most cases the variable signs are as expected. Exceptions include the negative signs for Emajor in both post-test equations though the variable is not statistically significant in either case. Emajor is positive and statistically significant in the pretest micro equation; economics majors scored about 1.2 points higher on the micro test than nonmajors, ceteris paribus. Emajor was positive but not significant in the macro pretest equation. Sex is positive and significant in the pretest macro equation (males scored about 1.2 points higher than females) but is not significant in the other equations. 
Table 7 Regression results for Trainers' programme, 2001-03

\begin{tabular}{|c|c|c|c|c|}
\hline \multirow[b]{2}{*}{ Regressors } & \multicolumn{3}{|c|}{ Dependent variable } & \multirow[b]{2}{*}{ PostMacro } \\
\hline & PreMicro & PostMicro & PreMacro & \\
\hline Constant & $\begin{array}{l}5.411^{* * *} \\
(8.337)\end{array}$ & $\begin{array}{l}5.533^{* * *} \\
(7.645)\end{array}$ & $\begin{array}{l}6.891^{* * *} \\
(10.481)\end{array}$ & $\begin{array}{l}7.524^{* * *} \\
(11.477)\end{array}$ \\
\hline Emajor & $\begin{array}{l}\text { 1.183\#\#\# } \\
(2.063)\end{array}$ & $\begin{array}{l}-0.300 \\
(0.542)\end{array}$ & $\begin{array}{l}0.840 \\
(1.445)\end{array}$ & $\begin{array}{l}-0.317 \\
(0.683)\end{array}$ \\
\hline Doc & $\begin{array}{l}-0.502 \\
(0.350)\end{array}$ & $\begin{array}{l}-0.156 \\
(0.114)\end{array}$ & $\begin{array}{l}-0.638 \\
(0.439)\end{array}$ & $\begin{array}{l}-1.023 \\
(0.887)\end{array}$ \\
\hline DEmajor & $\begin{array}{l}-0.199 \\
(0.111)\end{array}$ & $\begin{array}{l}1.040 \\
(0.604)\end{array}$ & $\begin{array}{l}1.427 \\
(0.781)\end{array}$ & $\begin{array}{l}2.441 \\
(1.680)\end{array}$ \\
\hline Master & $\begin{array}{l}0.036 \\
(0.048)\end{array}$ & $\begin{array}{l}0.479 \\
(0.669)\end{array}$ & $\begin{array}{l}0.559 \\
(0.735)\end{array}$ & $\begin{array}{l}0.699 \\
(1.158)\end{array}$ \\
\hline MEmajor & $\begin{array}{l}0.800 \\
(0.807)\end{array}$ & $\begin{array}{l}0.093 \\
(0.099)\end{array}$ & $\begin{array}{l}2.992 \\
(2.977)\end{array}$ & $\begin{array}{l}-0.389 \\
(0.476)\end{array}$ \\
\hline Russhome & $\begin{array}{l}\text { 2.498\#\#\# } \\
(4.212)\end{array}$ & $\begin{array}{l}0.463 \\
(0.737)\end{array}$ & $\begin{array}{l}\text { 2.597\#\#\# } \\
(4.324)\end{array}$ & $\begin{array}{l}0.746 \\
(1.493)\end{array}$ \\
\hline Ukhome & $\begin{array}{l}\text { 1.540\#\#\# } \\
(2.785)\end{array}$ & $\begin{array}{l}0.503 \\
(0.934)\end{array}$ & $\begin{array}{l}\text { 1.560\#\#\# } \\
(2.785)\end{array}$ & $\begin{array}{l}-0.001 \\
(0.002)\end{array}$ \\
\hline Russlang & $\begin{array}{l}0.370 \\
(0.775)\end{array}$ & $\begin{array}{l}\text { 2.870\#\#\# } \\
(6.291)\end{array}$ & $\begin{array}{l}-0.063 \\
(0.130)\end{array}$ & $\begin{array}{l}\text { 2.494\#\#\# } \\
(6.497)\end{array}$ \\
\hline Sex & $\begin{array}{l}0.369 \\
(0.739)\end{array}$ & $\begin{array}{l}-0.829 \\
(1.738)\end{array}$ & $\begin{array}{l}\text { 1.233\#\#\# } \\
(2.439)\end{array}$ & $\begin{array}{l}-0.190 \\
(0.466)\end{array}$ \\
\hline YrsTeach & $\begin{array}{l}-0.050 \\
(1.687)\end{array}$ & $\begin{array}{l}-0.023 \\
(0.797)\end{array}$ & $\begin{array}{l}-0.050 \\
(1.651)\end{array}$ & $\begin{array}{l}0.002 \\
(0.088)\end{array}$ \\
\hline Pre & --- & $\begin{array}{l}0.517 \# \# \# \\
(7.467)\end{array}$ & - - & $\begin{array}{l}0.455 \# \# \# \\
(7.904)\end{array}$ \\
\hline$R^{2}$ (adj.) & 0.139 & 0.397 & 0.196 & 0.428 \\
\hline SEE & 3.026 & 2.887 & 3.065 & 2.433 \\
\hline $\mathrm{F}$ & 4.234 & 12.957 & 5.879 & 14.589 \\
\hline
\end{tabular}

Note: Absolute values of $\mathrm{t}$ statistics are in parentheses. All $\mathrm{F}$ statistics are significant at 0.000 .

*** Significant at 0.01 (two-tail test)

\#\#\# Significant at 0.01 (one-tail test)

** Significant at 0.05 (two-tail test)

\#\# Significant at 0.05 (one-tail test) 
One interaction term, DEmajor, was not significant in any equation; having a doctorate in economics had no significant impact on pretest or post-test scores. The other interaction term, MEmajor, was significant in only the pretest macro equation. Those with a master's degree in economics scored 3.0 points higher than those without advanced degrees. This may suggest that macroeconomics received greater emphasis than microeconomics in advanced study programmes.

The number of years trainers taught economics ${ }^{13}$ is not significant in any equation, offering some support for the 'old dogs' theory that teaching experience added little to economic knowledge, possibly because much of this experience was spent teaching a non-mainstream version of the subject. The size of the four pretest micro and macro coefficients for Russhome and Ukhome range from 1.5 to 2.6 points and all are statistically significant. Apparently, the educational systems in Russia and Ukraine provided a better foundation in economics than did the systems in other countries. ${ }^{14}$ Although the signs on these variables are positive in the post-test regression no result was statistically significant.

Finally, the Russlang variable measures the difference between those who attended 'Russian language' Training sessions from those who attended 'English/Russian language' sessions. The sign on this variable is positive in three of the four equations (the macro pretest equation is the exception) but significant in only the two post-test equations. The coefficient values are notably high ( 2.9 in the micro post-test, 2.5 for the macro post-test). This result implies a large difference in the trainers' test performance based on which training session they attended. One explanation for these results is that trainers with relatively poor Russian language skills preferred to attend an 'English/Russian language' session, even though they were not fluent in English. If this interpretation is accurate, it would be beneficial to offer trainers a greater variety of language options with respect to testing and evaluation materials. It is impractical to offer future sessions in the native languages of over 20 different countries but translation of evaluation materials into more languages, even if lectures all still translated from English into Russian, may remove some of the possible distortion in post-test scores that is due solely to language difficulties.

\section{Conclusions}

The first question posed at the beginning of this paper - What did the trainers know? - was addressed through the calculation of pretest mean scores on microeconomics and macroeconomics test items given during each of 15 Training the Trainers sessions conducted from 1996-03. The trainers' mean test scores were compared to scores earned on the same test items by a norming sample of over 
2,700 US college students. The trainers in each of the sessions earned higher pretest mean scores than those of students in the norming sample. Trainers from the sessions offered in 1996-97 performed especially well on the pretests. Other pretest microeconomics mean scores differed little over time. Pretest macroeconomics mean scores were generally higher for trainers who attended sessions before 2000 than for trainers from sessions held after 2000.

The second question posed - What did the trainers learn? - was addressed through the calculation and analysis of post-test microeconomics and macroeconomics test scores. These scores reflect the enthusiasm and work effort of the trainers as well as the quality of the programmes and those who provided instruction for them. Here there are two evaluation standards: comparisons between mean scores achieved on the same test items by students in the US college student norming sample and the differences between the trainers' post-test and pretest scores. For all but one Training session the post-test microeconomics mean scores exceed the corresponding norming sample mean. The post-test macroeconomics mean scores all exceed the corresponding norming sample mean. Paired sample $t$-tests confirm that for all of the Training sessions post-test means scores are significantly greater than their respective pretest scores.

Regression analysis was conducted of the test scores from the 2001-03 Training sessions. Results from these regressions show that trainers from Russia and Ukraine earned higher pretest microeconomics and macroeconomics mean scores than trainers from other countries, and trainers who attended Russian language sessions earned higher post-test mean scores than trainers who attended Russian/English language sessions.

\section{References}

Becker, W. and Walstad, W.B. (1987) 'Statistical Methods in Economic Education Research' in W. Becker and W.Walstad (eds) Econometric Modeling in Economic Education Research, Boston: Kluwer-Nijhoff.

Brue, S. and MacFee, C. (1995) 'From Marx to Markets: Reform of the University Economics Curriculum in Russia', The Journal of Economic Education. 26(3). 182-194.

Cronbach, L.J. and Meehl, P.E. (1955) 'Construct Validity in Psychological Tests', Psychological Bulletin, 53, 281-302.

Kovzik, A. and Watts, M. (2002) 'Reforming Undergraduate Economics Instruction in Russia, Belarus, and Ukraine: Curriculum, Personnel, Clientele Issues', in M. Watts and W. Walstad (eds) Reforming Economics and Economic Teaching in Transition Economies, Northampton, MA: Edward Elgar.

Lumsden, K. G. and Scott, A. (1987) 'The Economics Student Reexamined: Male-female Differences in Comprehension', The Journal of Economic Education, 18(4), 365-375. 
Lynch, G. (1990) 'The Effect of Teacher Course Work on Student Learning: Evidence from the TEL', The Journal of Economic Education, 21(3), 287-296.

Saunders, P. (1991) Test of Understanding in College Economics (3rd edn.), New York: Joint Council on Economic Education.

Walstad, W. and Rebeck, K. (2001) 'Teacher and Student Understanding in the Transition Economies, The Journal of Economic Education, 32(1), 58-67.

Walstad, W. and Robson, D. (1997) 'Differential Item Functioning and Male-female Differences on Multiple-choice Tests in Economics', The Journal of Economic Education, 28(2), 155-171.

Walstad, W. and Soper, J. (1988) 'A Report Card on the Economic Literacy of U.S. High School Students', American Economic Review, 78(2), 251-256.

Watts, M. and Bosshardt, W. (1990) 'Instructor Effects and Their Determinants in Precollege Economic Education', The Journal of Economic Education, 21(3), 265-276.

\section{Notes}

1 Although international pre and post-tests were conducted, test items were not the same in all years of the programmes. Therefore, this paper does not analyse these test scores.

2 There were 202 participants from Russia and 174 from Ukraine ( $27.1 \%$ and $23.3 \%$ of the total). Other nations represented were: Kazakhstan (61), Uzbekistan (47), Latvia (33), Belarus (33), Kyrgyzstan (30), Bulgaria (23), Estonia (16), Georgia (16), Slovakia (16), Lithuania (16) Romania (14), Poland (12), Tajikistan (11), Croatia (10), Albania (10), Azerbaijan (7), Armenia (6), Moldova (4), Turkmenistan (3), Hungary (1) and Mongolia (1).

3 The authors describe curricular changes in economics at Belarus and Kiev State Universities as well.

4 Although a Training programme was conducted in 1995-96, results are not available for the individual items that comprised the microeconomics and macroeconomics tests for this group. Therefore, data analysed in this paper cover 15 Training sessions from 1996 to 2003.

5 Admittedly, this norming sample does not offer an ideal basis for comparison. The (non-random) norming sample for the TUCE included students from over 40 two-year and four-year colleges and universities. For many of these students the scores they received on the TUCE did not affect the grades they received in their courses; therefore, the sample means may understate their knowledge of micro and macroeconomics. Despite their shortcomings, the mean scores earned by students from the norming samples provide a useful benchmark to evaluate the trainers' test scores.

6 The 18 macroeconomics and 17 microeconomics TUCE items used to evaluate the trainers will be provided by the author to interested readers.

7 The total number of participants (755) from Table 2 reflects the number who began the programme and completed participant information forms. The number of completed post-tests is 746 .

8 Participants classified as having earned a master's as their highest academic degree also included 'candidates' or persons who were in the process of earning a degree higher than the master's. 
$9 \alpha=(\mathrm{n} / \mathrm{n}-1)\left(1-\varepsilon \mathrm{V}_{\mathrm{i}} / \mathrm{V}_{\mathrm{i}}\right) ; \mathrm{n}=$ the number of test items; $\mathrm{V}=$ the variance of the total test; $\varepsilon V_{i}=$ the sum of the variance of individual items.

10 Cronbach's alpha is designed to measure a one-dimensional construct. The data used in this study have a multidimensional structure; this may account for the low $\alpha$ value (0.170) for the 1996-97 Russian language group.

11 Some even argue the opposite is true: some of those with advanced degrees may be less open to learning that conflicts with their preconceived beliefs.

12 Russian trainers received instruction and completed evaluation materials in their native language; this may have had a positive influence on their test scores. The two sessions that featured instruction in the Ukranian language were held before 2001.

13 Separate regressions were run with 'years teaching' substituting for the 'years teaching economics' variable but this made little difference in the regression results.

14 Assuming that the Ukraine and Russia began reforming economic education before other countries, these results may also be related to when these reforms began.

\section{Acknowledgments}

Support for this research project was provided by the National Council on Economic Education through the Cooperative Education Exchange Program funded by US Department of Education in coordination with the US Department of State.

\section{Contact details}

Edward M. Scahill

Associate Professor, Economics

Department of Economics

320 Madison Avenue

University of Scranton

Scranton, PA 18510-4602

USA

email:ems353@scranton.edu 